\title{
MEMBANGUN TOLERANSI BERAGAMA BERLANDASKAN KONSEP MODERASI DALAM AL-QUR'AN DAN PANCASILA
}

\author{
Hilmi Ridho \\ Pascasarjana Universitas Ibrahimy \\ Pondok Pesantren Salafiyah Syafi ìyah Sukorejo Jl. KHR. Syamsul Arifin, Sukorejo, \\ Banyuputih, Kabupaten Situbondo, Jawa Timur \\ Email: hilmikamila241@gmail.com
}

\begin{abstract}
The issue of intolerance in the name of Islam has increasingly made people traumatized and restless by the decline in human values. Every day, the world is offered a display of Islam that is delivered by angry Muslims. The world also wonders where is the rahmah's behavior from religion which is said to carry the teachings of mercy and compassion. When there are groups that raise the flag of Islam while destroying humanity, the world is increasingly questioning the practice of Islam that rahmatan lil 'alamin, peace, and respect for humans. The decline in the value of humanity and tolerance is influenced by a weak understanding of the teachings of moderate Islam and the inclusion of Wahhabism as the ancestors of radicalism. This paper is examined as a form of concern for what has befallen Islam with the treatment that has no humanity. The Koran as a source of Islamic religious law with its verses, provides us with an understanding of the meaning of moderate Islam that is true. Whereas Pancasila as an absolute source of law in Indonesia gives the meaning of religious tolerance through all the principles of Pancasila; God, humanity, unity and justice. These two sources of law should be applied in daily life as a solution to overcome intolerance that often carries the name of Islam as a tool to fight other religions that are not in line with the teachings of Islam.
\end{abstract}

Keywords: Religious Tolerance, Moderation, Alquran and Pancasila.

\section{Pendahuluan}

Ajaran agama Islam baik yang bersifat tekstual maupun kontekstual selalu mewarnai sejarah peradaban Islam. Ada sebagian kelompok mengatakan bahwa teks-teks keagamaan sudah seharusnya diterapkan secara proporsional, sehingga orisinalitas ajaran agama Islam dapat terjaga. Dalam agama Islam, yang menjadi sumber rujukan beragama adalah Alquran dan Hadis. Akan tetapi, realitasnya menunjukkan bahwa wajah agama Islam sangat beragam, ada berbagai golongan Islam yang terkadang memiliki ciri khas dan praktik keagamaan tersendiri sesuai dengan tradisi dan keyakinan masing-

This work is licensed under Creative Commons Attribution Non Commercial 4.0 International License Available online on: http://riset.unisma.ac.id/index.php/natiq/index 
masing. Perbedaan ini tampaknya sudah menjadi kewajaran dan bahkan bisa dikatakan sebagai suatu rahmat.

Namun, yang menjadi pertanyaannya saat ini adalah bisakah dari perbedaan itu tidak saling menyalahkan satu sama lain, saling menghormati, tidak menyatakan menang sendiri, dan bersedia berdialog. Dengan demikian, tampak bahwa perbedaan tersebut merupakan rahmat. Bila hal ini yang dijadikan pedoman dalam kehidupan sehari-hari baik beramal dan beragama, maka inilah pada dasarnya yang disebut dengan konsep Islam moderat. Kendati dalam ajaran agama Islam tidak dijelaskan secara detail tentang konsep Islam moderat, tetapi untuk membangun prinsip agama Islam yang santun dan mau memahami golongan lain maka patut kiranya mengaktualisasikan konsep Islam moderat sejak dini.

Pada dasarnya tidaklah sulit mencari rujukan mengenai pemahaman Islam moderat dalam sejarah perkembangan Islam, baik di wilayah asal Islam itu sendiri maupun di Indonesia. Dari aspek wilayah tempat turunnya Islam pertama kali, konsep moderat bisa merujuk pada praktik yang dilakukan oleh Nabi Muhammad dana para Sahabatnya. Sedangkan di Indonesia, konsep Islam moderat bisa merujuk kepada para penyebar agama Islam yakni Walisongo.

Negara Indonesia menahbiskan dirinya sebagai salah satu bangsa yang memiliki masyarakat multikultural dengan keanekaragaman budaya, agama, suku, dan bahasa yang dimilikinya. Bila dikelola dengan baik dan benar, keanekaragaman tersebut dapat menjadi sebuah rahmat tersendiri bahkan menjadi keunikan dan kekuatan tersendiri. Namun di saat bersamaan, realita pluralitas demikian itu juga dapat menjadi tantangan besar jika tidak disikapi dengan bijak, adil dan arif, bahkan juga dapat menjadi ancaman perpecahan dan perseteruan khususnya problem agama yang dapat mengoyak keamanan sosial. (Darlis, 2017). Sudah sepatutnya setiap agama belajar menegakkan prinsip tawassuth (moderat), ta aadul (keadilan), dan, tawazun (keseimbangan) sebagaiamana tiga prinsip tersebut ada pada prinsip agama Islam yang disatukan menjadi 'wasathiyyah' (moderasi).

Namun realitanya, banyak oknum yang merusak prinsip-prinsip ajaran agama Islam (tawassuth, ta`aadul, dan, tawazun), membawa nama agama sebagai alat peperangan antar umat beragama di Indonesia. Mereka ingin membentuk kembali negara khilafah dengan menjadikan agama Islam sebagai biang kerok langgengnya prinsip kekerasan, kezaliman, dan intoleransi. Seperti diketahui, dunia dewasa ini diresahkan oleh fenomena merosotnya nilai kemanusian, diresahkan oleh kekacauan seperti yang terjadi di Timur Tengah, dengan munculnya kelompok mengatasnamakan Islam yang berperilaku sangat bertentangan dengan Islam. Setiap hari dunia disuguhi tampilan Islam yang dibawakan oleh kaum muslimin yang marah. Dunia pun bertanya-tanya dimanakah perilaku rahmah dari agama yang katanya membawa ajaran damai dan kasih sayang (Bisri, 2015). 
Di dalam negeri sendiri ada fenomena gerakan radikalisme dan terorisme berbasis agama yang menjadi keprihatinan kita semua. Dalam beberapa tahun sebelumnya Indonesia dihadapkan dengan aksi teror simultan, serangan demi serangan dilancarkan oleh kelompok teroris biadab yang mengancam stabilitas keamanan nasional dan integrasi sosial. Mulai dari aksi pembakaran kalimat tauhid oleh oknum banser, aksi bom bunuh diri (suicide bomber) yang terjadi di tiga gereja di Surabaya (News Indonesia, 2018), kemudian disusul adanya ledakan bom di rusunawa Sidoarjo (Detik News, 2018). Aksi teror tersebut hampir selalu memakan korban, baik diri pelakunya maupun warga yang tidak berdosa. Di samping itu, peristiwaperistiwa tersebut juga menimbulkan trauma psikologis bagi para korban yang masih hidup dan berimplikasi terhadap busana kaum muslim (cadar, gamis, sorban, dan kopyah) yang dianggap sebagai busana kelompok teroris dalam menjalankan teror di berbagai tempat.

Untuk mendukung sebuah penelitian, penulis akan memaparkan beberapa penelitian yang berkaitan dengan fokus penelitian yang dikaji oleh penulis, antara lain; pertama, jurnal yang ditulis oleh Roro Fatkhin (2017) yang berjudul "Keadilan Sosial Dalam Perspektif Al-Qur`an dan Pancasila". Dalam tulisan tersebut menghasilkan simpulan bahwa konsep keadilan ekonomi memiliki ciri khas tersendiri dalam Alquran, yaitu; keadilan ekonomi dalam Alquran harus dilandasi dengan keimanan, keadilan ekonomi dalam Alquran memiliki nilai normatif, dan keadilan ekonomi memprioritaskan terhadap kebahagiaan manusia. Sedangkan keadilan ekonomi dalam kaitannya dengan Pancasila merupakan sifat dari masyarakat yang adil, makmur, dan terciptanya kebahagiaan yang bersifat material dan spiritual.

Pada dasarnya penelitian ini memiliki persamaan dengan penelitian yang dilakukan oleh Roro Fatikhin yaitu dari aspek sudut pandangnya, namun ada letak perbedaan yang prinsip yaitu dari aspek fokus penelitiannya. Penulis lebih memfokuskan kepada kajian toleransi dan moderasi yang tertuang dalam Alquran dan Pancasila, sedangkan Roro Fatikhin memfokuskan kajiannya kepada keadilan yang termaktub dalam Alquran dan Pancasila, sehingga penelitian ini jelas berbeda dengan apa yang dikaji oleh peneliti sebelumnya.

\section{Hasil dan Pembahasan}

\section{Pengertian Moderasi}

Istilah moderasi dalam Alquran dikenal dengan kata "wasathan", yang memiliki arti jalan tengah di antara dua batas, keadilan, atau yang biasa-biasa saja. Selain itu, wasathan juga bermakna menjaga diri dari bersikap melampaui batas (Al-Asfahany, 2009). Sedangkan dalam Mu'jam al-Wasit wasathan memiliki makna "Adulan" dan "Khiyaran" yang berarti sederhana dan terpilih (Ali, 1973).

Ibnu 'Asyur mendefinisikan kata "wasath" dengan dua makna; Pertama, definisi menurut etimologi, kata wasath berarti sesuatu yang ada 
di tengah, atau sesuatu yang memiliki dua belah ujung yang ukurannya sebanding. Kedua, definisi menurut terminologi bahasa, makna wasath adalah nilai-nilai Islam yang dibangun atas dasar pola pikir yang lurus dan pertengahan, tidak berlebihan dalam hal tertentu (Asyur, 1979).

Dari penjelasan kedua tokoh mengenai pengertian moderasi, ada titik temu antara makna wasathan yang dikemukakan oleh Ibnu 'Asyur dan Al-Asfahany, yaitu tidak adanya pertentangan makna antara yang satu dengan yang lainnya. Dengan demikian dapat disimpulkan bahwa wasathan adalah sebuah kondisi terpuji yang menjaga seseorang dari bersikap ifrath (berlebih-lebihan) dan muqashshir (mengurang-ngurangi sesuatu). Sifat moderat umat Islam adalah anugerah yang diberikan Allah SWT secara khusus. Saat mereka konsisten menjalankan ajaran-ajaran Allah SWT, maka saat itulah mereka menjadi umat terbaik dan terpilih. Sifat ini telah menjadikan umat Islam sebagai umat moderat dalam segala urusan, baik urusan agama atau urusan sosial di tengah-tengah masyarakat.

Pemahaman moderat merupakan salah satu ciri khas ajaran agama Islam yang tidak dimiliki oleh agama-agama lain. Pemahaman moderat menyeru kepada dakwah Islam yang toleran, menentang segala bentuk pemikiran liberal dan radikal. Liberal dalam arti memahami Islam melalui tataran kontekstual dengan standar hawa nafsu dan murni logika. Sedangkan Radikal dalam arti memaknai Islam melalui tataran tekstual yang menghilangkan fleksibilitas ajarannya, sehingga terkesan stagnan dan jumud serta tidak mampu membaca realitas hidup. Sikap moderasi agama Islam adalah suatu sikap penolakan terhadap ekstremisme dalam bentuk kezaliman dan kebatilan. Ia tidak lain merupakan cerminan dari fitrah asli manusia yang suci dan belum tercemar pengaruh-pengaruh negatif (Asyur, 1979).

Konsep moderasi Islam bukanlah tanpa landasan, hal itu justru muncul dengan landasan teologis Qur`ani yang sangat kuat. Istilah moderasi Islam adalah bagian dari ajaran Islam yang universal, bahkan bisa dikatakan inti dari ajarannya. Di samping itu, moderasi Islam memiliki padanan dengan istilah arab yaitu ummatan wasathan atau al-din al-wasath. Ummatan wasathan berarti golongan tengah yang tidak menganut paham ekstremisme. Artinya umat yang adil dan terbuka dengan siapapun serta siap bekerjasama dalam membangun kemaslahatan umat dengan prinsip toleransi, kemanusiaan, dan menghargai perbedaan. Salah satu konsep moderasi Islam yaitu menentang penindasan, kezaliman, diskriminasi dan ketdakadilan (Arifinsyah, 2016).

\section{Konsep Moderasi Perspektif Alquran dan Pancasila}

Islam sebagai agama yang terakhir memiliki banyak ciri khas yang membedakannya dari agama yang lain. Ciri khas Islam yang paling 
menonjol adalah tawassuth, ta'adul, dan tawazun. Ini adalah beberapa ungkapan yang memiliki arti sangat berdekatan atau bahkan sama. Oleh karena itu, tiga ungkapan tersebut bisa disatukan menjadi "wasathiyyah" (Muhajir, 2018).

Watak moderasi Islam ini dinyatakan sendiri oleh Allah SWT di dalam Alquran. Kata-kata wasath dengan berbagai derivasinya dalam Alquran berjumlah 3 kali yaitu surah al-Baqarah ayat 143, 238, dan surah al-Qalam ayat 28:

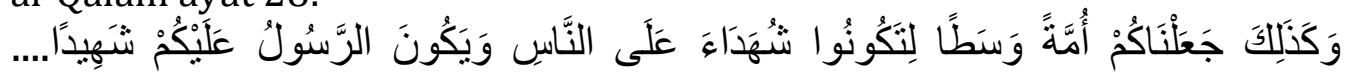

"Dan demikian pula kami telah menjadikan kamu (umat Islam) 'umat pertengahan agar kamu menjadi saksi atas perbuatan manusia dan agar Rasul (Muhammad) menjadi saksi atas perbuatan kamu." (Qs. al-Baqarah: 143).

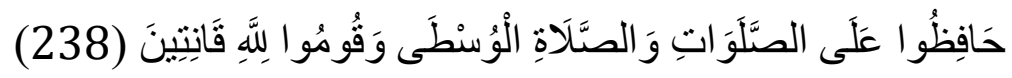

"Peliharalah semua salat dan salat wustha dan laksanakanlah (salat) karena Allah dengan Khusuk." (Qs. al-Baqarah: 238).

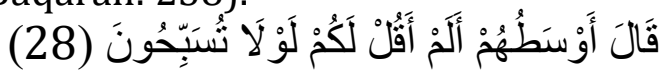

"Berkatalah seseorang yang paling bijak di anatara mereka, bukankah aku telah mengatakan kepadamu, mengapa kamu tidak bertasbih (kepada Tuhanmu)." (Qs. al-Qalam: 28).

Adapun makna "ummatan wasathan" pada surat al-Baqarah ayat 143 adalah umat yang adil dan terpilih. Maksudnya, umat Islam ini adalah umat yang paling sempurna agamanya, paling baik akhlaknya, paling utama amalnya. Allah SWT telah menganugerahi ilmu, kelembutan budi pekerti, keadilan, dan kebaikan yang tidak diberikan kepada umat lain. Oleh sebab itu, mereka menjadi "ummatan wasathan", umat yang sempurna dan adil dalam menjadi saksi bagi seluruh manusia di hari kiamat nanti (Asyur, 1984).

Nabi Muhammad SAW sendiri menafsirkan kata wasathan dalam firman Allah SWT di atas dengan adil (Al-Dimisqy, 2000), yang berarti seimbang dan menempatkan sesuatu pada tempatnya. Memberlakukan hukum azimah dalam kondisi normal dan membrikan hukum rukhshah dalam keadaan terdesak itu adil. Perubahan fatwa disebabkan karena berubahnya situasi dan kondisi serta perbedaan penetapan hukum karena perbedaan kondisi dan psikologi seseorang adalah adil (Muhajir, 2018).

Selain ayat di atas, ada beberapa ayat yang menunjukkan watak moderasi dalam Islam, misalnya firman Allah:

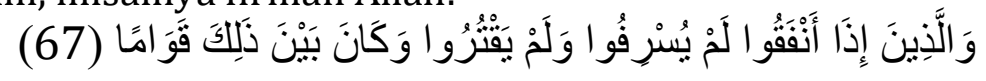


"Dan orang-orang yang apabila membelanjakan (harta), mereka tidak berlebihan, dan tidak (pula) kikir, dan adalah (pembelanjaan itu) di tengahtengah antara yang demikian." (Qs. al-Furqan: 67).

Dalam ayat lain dinyatakan juga tentang watak wasathiyyah yang dimiliki oleh agama Islam;

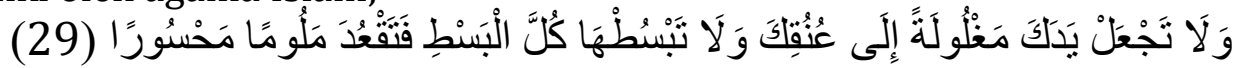
"Dan janganlah kamu jadikan tanganmu terbelenggu pada lehermu dan janganlah kamu terlalu mengulurkannya karena itu kamu menjadi tercela dan menyesal." (Qs. al-Isra`: 29).

Moderasi berarti jalan tengah atau keseimbangan anatara dua hal yang berbeda atau berkebalikan, seperti keseimbangan ruh dan jasad, antara dunia dan akhirat, anatara individu dan masyarakat, antara idealitas dan realitas, antara yang baru dan yang lama, antara ilmu dan amal, antara sarana dan tujuan, antara optimis dan pesimis, dan seterusnya.

Sedangakan konsep moderasi dalam perspektif Pancasila sebagai sumber hukum mutlak di Indonesia tidaklah berbeda, karena nilai-nilai yang terkandung dalam asas-asas Pancasila sangat selaras dengan ajaranajaran agama Islam; baik secara konseptual (sebagaimana yang tertuang dalam kitab suci) dan secara praksis (sebagaimana yang dicontohkan oleh Nabi).

Pancasila sebagai pedoman dasar Negara Indonesia diharapkan mampu merawat keberagaman, kemajemukan, dan mempersatukan perbedaan di bawah naungan panji Bhineka Tunggal Ika. Artinya, kekhasan dan keunikan masing-masing komunitas masyarakat diapresiasi sebagai kepingan-kepingan khazanah bangsa dan energi positif dalam mengarungi perkembangan zaman. Dengan demikian, Pancasila dipandang sebagai simbol kesepakatan antar berbagai golongan masyarakat dalam mewujudkan aspirasi bersama, yakni menjadi bangsa yang berdaulat, adil, dan makmur sesuai dengan amanat Mukadimah UUD 1945.

Pancasila sebagai sumber hukum di Indonesia mengakui adanya pluralitas beragama masing-masing individu, menghormati semua agama yang ada di Indonesia dan memelihara hubungan baik antar pemeluk dan pemuka agama yang bernaung di bawah Negara demokrasi ini. Adanya sikap tersebut menunjukkan bahwa Pancasila memiliki prinsip moderat antar beragama. Sehingga seluruh agama yang ada di Negara Indonesia merasa aman, damai, dan tentram dalam menjalankan ibadah sesuai dengan masing-masing keyakinan mereka.

Bunyi Pancasila pertama sangat menegaskan prinsip moderat dalam beragama, artinya sila "Ketuhanan Yang Maha Esa" menekankan 
pentingnya pemahaman keagamaan yang moderat dan berorientasi pada keharmonian antar sesama umat beragama. Sikap moderat tersebut dapat dilihat dari kata "Ketuhanan" yang menempel pada sila pertama (sekalipun penduduk Indonesia sarat dengan pemeluk agama Islam), karena apabila bunyi sila pertama "Ketuhanan Yang Maha Esa" diganti menjadi "Allah Yang Maha Esa", maka hal itu mengakibatkan seolah-olah mendiskriminasi kepada agama selain Islam dan tidak mengakui adanya pluralitas beragama di Indonesia.

Salah satu implikasi dari pemahaman sila "Ketuhanan Yang Maha Esa" adalah memutlakkan Tuhan sebagai satu-satunya Dzat Yang Maha Mutlak sehingga menolak dan melepaskan diri dari belenggu absolutisme dan otoritarianisme. Tidak dibenarkan suatu pemikiran maupun perilaku yang memutlakkan sesuatu selain-Nya. Bagi seorang muslim, paham Ketuhanan Yang Maha Esa adalah cerminan dari prinsip tauhid yang merupakan pedoman utama bagi setiap muslim dalam menjalani kehidupan, yakni senantiasa tunduk dan pasrah sepenuhnya kepada Allah.

Lalu sila "Kemanusiaan Yang Adil dan Beradab" juga menegakkan prinsip moderat berupa menitikberatkan pada penghormatan hak-hak asasi sesama warga guna memenuhi rasa keadilan dan keberadaban tanpa memandang status sosial. Oleh sebab itu, sudah selayaknya masyarakat Indonesia menjaga prinsip adil dan beradab kepada sesama terutama dalam beragama.

Kemudian sila "Persatuan Indonesia", yang menjadi pantulan dari semangat bhinneka tunggal ika. Hal ini menjadi sebuah bukti pengakuan realita pluralitas beragama dan kemajemukan masyarakat bagi lahirnya negara dan bangsa Indonesia, hal ini juga merupakan sikap moderasi dalam Pancasila. Sehingga wajar apabila Pancasila didengungkan sebagai jiwa dan ruh dari masyarakat Indonesia. Tanpa persatuan masyarakat Indonesia akan pecah, karena persatuan adalah hal yang paling pokok dalam membangun bangsa yang sejahtera, aman dan damai.

Konsep moderasi dalam sila "Kerakyatan Yang Dipimpin oleh Hikmah Kebijaksanaan dalam Permusyawaratan atau Perwakilan", adalah berupa perwujudan demokrasi politik sebagai konsekuensi atas pengakuan kedaulatan rakyat dan penghormatan terhadap hak-hak setiap warga negara. Dalam sistem demokrasi, pemimpin pada hakikatnya adalah pembantu masyarakat. Oleh karenanya, sudah sepatutnya pemimpin melayani masyarakat yang membutuhkan hak-haknya dengan adil dan bijak tanpa memandang status sosial; kaya atau miskin, normal ataupun disabilitas, berkedudukan maupun tidak. Dengan demikian sikap moderat akan terwujud sebagaimana yang diharapakan oleh ajaran agama Islam dan Pancasila sebagai ideologi negara.

Demikian pula bunyi Pncasila kelima "Keadilan Sosial bagi Seluruh Rakyat Indonesia" yang juga di dalamnya mengandung prinsip moderat 
kepada seluruh rakyat Indonesia. Terkait dengan masalah hubungan beragama antara muslim dan non muslim, Pancasila kelima mengacu pada seluruh rakyat Indonesia tanpa memilah-milah perbedaan suku, etnis, ras dan agama. Jadi keadilan dalam sila kelima merupakan sikap moderat kepada seluruh rakyat Indonesia, sementara nilai-nilai keseluruhan yang tertuang dalam pancasila seperti persatuan dan kesatuan, kemanusisan, dan prinsip-prinsip berdialog, menjadi konsep moderasi dan kata kunci serta rumusan yang paling primordial dalam menjalin hubungan yang baik dalam beragama antara muslim dan non muslim.

\section{Sejarah Islam Moderat di Indonesia}

Sejatinya kedatangan Islam di bumi Nusantara ini pada awalnya telah menampakkan sifat keramahannya kepada setiap masyarakat. Sebagai sebuah agama dan kekuatan kultur, Islam disebarkan dengan cara yang santun, damai, dan tidak memaksa pemeluk agama lain untuk masuk agama Islam. Di samping itu, Islam menghargai setiap budaya yang tengah berjalan, bahkan menjadikan budaya tersebut sebagai media dakwah dalam menyebarkan agama Islam. Ternyata sikap toleran inilah yang banyak menarik simpatik masyarakat Indonesia pada saat itu untuk mengikuti ajaran Islam. Sementara itu, Walisongo adalah arsitek yang handal dalam membangun agama Islam yang santun dan damai di Indonesia.

Sebagai agen unik jawa pada abad XV-XVI, Walisongo memadukan aspek sekuler dan spiritual dalam menyiarkan agama Islam. Posisi mereka dalam kehidupan sosio-kultural di tanah Jawa begitu memikat hati masyarakat hingga bisa dikatakan Islam tidak pernah menjadi the religion of java bila sufisme yang dikembangkan oleh Walisongo tidak mengakar di tengah-tengah masyarakat. Hal ini menunjukkan bahwa ajaran agama Islam yang diperkenalkan oleh Walisongo di tanah Jawa hadir dengan penuh kedamaian, walaupun terkesan lambat namun meyakinkan. Fakta sejarah menunjukkan bahwa dengan cara menerapkan prinsip toleransi pada setiap tradisi lokal, serta memodifikasinya ke dalam ajaran agama Islam dengan berpedoman terhadap prinsip-prinsip agama Islam, maka dapat menarik minat tokoh masyarakat, bangsawan, dan kelompok mayoritas untuk mempelajari agama Islam. Terbukti agama baru ini dipeluk oleh bangsawan-bangsawan serta mayoritas masyarakat Jawa di pesisir utara (Mas`ud, 2006).

Penyebaran agama Islam yang dipelopori oleh Walisongoo adalah perjuangan yang mengimplementasikan cara-cara sederhana, anatara lain; pertama, tidak mengusik tradisi lokal yang sudah menjadi budaya di masyarakat. Kedua, menggunakan pendekatan yang konkret dan realistis. Ketiga, menerapkan konsep elastisitas yang mampu menyatu dengan kehidupan masyarakat. Model ini menunjukkan keunikan Walisongo 
sebagai sufi Jawa yang mampu menyerap elemen budaya lokal dan asing, sehingga dalam waktu yang sangat singkat mampu merangkul setiap kalangan.

Menurut Abdul Mun `im, mengatakan bahwa pada zaman Walisongo proses pergulatan Islam dengan kebudayaan setempat terlihat sangat intensif. Masa ini merupakan masa peralihan besar dari Hindu-Jawa yang mulai pudar menuju fajar zaman Islam. Keramahan terhadap tradisi dan budaya setempat itu diramu menjadi watak dasar budaya Islam pesantren. Wajah seperti itulah yang manjadikan Islam begitu mudah diterima oleh berbagai etnis yang ada di Nusantra. Hal ini terjadi karena ada kesesuaian antara agama Islam dan kepercayaan lama. Setidaknya, kehadiran Islam tidak mengusik kepercayaan lama, tetapi sebaliknya kepercayaan tersebut diapresiasi dan kemudian diintegrasikan ke dalam doktrin dan budaya Islam (Mun `im, 2007).

Tampaknya Walisongo menyadari langkah apa yang seharusnya dilakukan untuk menyebarkan Islam di bumi Nusantara. Mereka memahami bahwa ajaran agama Islam harus dikontekstualkan, tanpa mengurangi dan menghilangkan prinsip dan esensi ajaran agama Islam sesuai dengan kondisi tempat Islam yang disebarkan. Inilah yang kemudian dikenal dengan konsep "pribumisasi Islam". Konsep ini bertujuan untuk mencairkan karakter dan pola Islam sebagai suatu yang normatif dan menjadi sesuatu yang kontekstual. Dalam konsep tersebut tercermin bagaimana Islam sebagai ajaran yang normatif mengakomodasikan ajarannya masuk ke dalam kebudayaan yang berasal dari manusia tanpa menghilangkan identitas setiap individu (Rahmat, 2003). Dengan demikian, Islam akan mampu beradaptasi dan dinamis dalam merespon problem dinamika zaman. Di samping itu, sifat elastisitas agama Islam akan mampu berdialog dengan kondisi masyarakat yang berbeda-beda dari setiap sudut. Kemampuan beradaptasi secara kritis inilah yang sesungguhnya akan menjadikan Islam dapat benar-benar relevan dengan peralihan zaman dan tempat.

Jadi yang perlu dipahami dari penjelasan di atas adalah bahwa agama dan budaya tidak bisa dipisahkan. Sebab, disaat agama turun ke dataran empirik, maka ia pasti akan berhadapan dengan serangkaian realitas sosial budaya yang sering kali bertentangan dan tidak sesuai dengan ajaran agama yang hendak dikembangkan. Perselingkuhan antara agama dan budaya merupakan sunatullah yang perlu dipahami dan direnungkan, sehingga tidaklah benar membeda-bedakan budaya dengan agama. Budaya adalah pemikiran manusia yang profan atas teks-teks keagamaan yang sakral. Dengan demikian, relasi antara agama dengan budaya dalam pemikiran umat Islam sangatlah erat. Memahami ajaran agama Islam tanpa mengikuti penguasaan intelektual para pendahulu amat sulit mencapai titik kesempurnaan. Namun, budaya bukanlah hal 
yang mutlak, ia tetap dalam kondisi tidak sempurna sebagai buah pemikiran yang sarat akan nilai normatif tanpa ada dukungan dari agama. Sehingga agama dan budaya, ibarat dua sisi mata uang yang berbeda namun tidak bisa dipisahkan. Keduanya harus disikapi secara proporsional dan tidak boleh dilebih-lebihkan atau dikurangi dari kepastian sebenarnya.

\section{Faktor Utama Penyebab Intoleransi Beragama}

\section{a. Paham Wahabisme}

Mayoritas para peneliti menyatakan bahwa paham Wahabisme merupakan faktor utama penyebab timbulnya kekerasan beragama di kawasan Timur Tengah. Paham Wahabisme memiliki dua hal sinergis dan strategis yaitu; pertama, kekuasaan politik yang digunakan untuk melakukan ekspansi wilayah dan penyebaran ajaran. Kedua, aliran keagamaan yang bersifat radikal (Najib, 2009). Tuduhan ini bukan tanpa mendasar, kelompok Wahabi dan pengikutnya menggunakan kekuasaan politik sebagai media dalam memenyebarkan ajarannya. Selain itu, metode penyebarannya menggunakan kekerasan yang menyebabkan seolah-olah ajaran agama Islam itu kaku dan keras. Atas dasar itu, Prof. Abu Zahrah menganggap kelompok Wahabi hampir sama dengan kelompok Mu'tazilah dan Khawarij. Keduanya menjadikan kekuasaan politiknya sebagai alat untuk memerangi orang-orang berbeda pendapat dan memerangi orang yang tidak mau mengikuti ajarannya (Zahrah, t.t).

Untuk menyebarkan ajarannya dan ekspansi wilayah, kelompok Wahabi menyerang dan memberantas tradisi masyarakat yang dianggap bid 'ah dan berseberangan dengan ajaran tauhid. Dalam rangka memurnikan ajaran tauhid, mereka merusak simbol-simbol budaya yang dianggap akan menimbulkan kemusyrikan. Oleh sebab itu, seorang tokoh terkemuka Khaled M. Aboe El-Fadl menulis dengan nada geram mengenai paham Wahabisme tersebut, ia mengatakan "setiap kelompok radikal Islam yang hingga tingkat berbeda dikecam oleh dunia, seperti Taliban dan al-Qa'ida yang sangat dipengaruhi oleh pemikiran Wahabi" (El-Fadl, 2016).

Adapun ciri-ciri utama ajaram fikih Wahabi yang menjadi penyebab langgengnya kekerasan, antara lain; hukumnya yang bersifat pasti, penetapannya yang bersifat tegas, dan kesimpulannya yang tidak bisa digugat. Mereka tidak mau menerima sebuah pendapat yang bersumber dari mazhab hukum tertentu dan menyatakan bahwa tidak ada alasan bagi seorang muslim untuk mengikatkan diri pada ketetapan tertentu. Pandangan yang demikian mengakibatkan pada lahirnya sebuah kecenderungan memahami ajaran agama Islam dalam pengertiannya yang literal dan tekstual. Kecenderungan tersebut 
dikembangkan oleh Wahabi dan dijadikan sebuah doktrin dalam ajarannya, hingga hal itu dapat menghilangkan dimensi kontekstual dari prinsip-prinsip ajaran agama Islam. Tendensi seperti ini juga dapat menghalangi umat Islam untuk memahami pesan yang terkandung dalam Alquran sebagai instrumen ketuhanan yang memberikan panduan nilai normatif bagi kehidupan manusia.

Kelompok Wahabi mengeklaim bahwa mereka tidak pernah terlibat dalam kegiatan intelektual yang mencoba mengadaptasikan pesan dan makna ajaran agama Islam ke dalam kondisi sosial yang terjadi saat ini. Anggapan mereka tentang pesan dan makna ajaran agama Islam, sebagian besar sudah tercantum dalam Alquran dan Hadis, dan yang perlu dilakukan saat ini adalah menerapkannya ke dalam kehidupan empirik. Menurut mereka inilah yang dimaksud dengan memperjuangkan Islam secara keseluruhan tanpa melihat perubahan sosial-budaya yang dialami masyarakat muslim saat ini. Kultur demikian, pada dasarnya tidak relevan dengan konteks sosioantropologis dan basis kultural masyarakat Indonesia. Secara sosioantropologis, masyarakat Indonesia tidak pernah mengenal ajaran agama yang sifatnya ideologis dan eksklusif, justru sebaliknya mereka lebih tertarik dan menyukai ajaran agama yang menjunjung tinggi toleransi dan keterbukaan, tidak menyukai konflik dan akulturatif.

Masyarakat Indonesia memiliki daya serap yang sangat tinggi dalam hal menerima ajaran agama, terbukti dengan munculnya berbagai macam praktik ritual yang beragam dan kemampuan masyarakat hidup berdampingan dengan agama yang berbeda. Misalnya pada abad ke-VII dan VIII pemeluk agama Hindu-Budha mampu hidup harmonis dan membangun tradisi secara bersamasama. Bahkan disaat agama Islam masuk tradisi tersebut tidak pernah berubah sama sekali, justru hal itu menjadi sinkretisasi dan akulturasi. Dengan watak yang demikian, agama apapun bisa masuk dan terserap ke dalam kehidupan masyarakat secara santun dan damai, sehingga tidak menimbulkan konflik dan gejolak sosial.

\section{b. Paham Radikalisme}

Aksi radikalisme dan terorisme di Indonesia menjadi salah satu kajian yang menarik memasuki abad ke-21. Selain dipengaruhi faktor kekerasan, juga diprngaruhi oleh kesalahan individu umat Islam yang cenderung literalistik dalam memahami teks Alquran dan Hadis (Azra, 1993). Ditambah lagi dengan sikap umat Islam yang cenderung eksklusif dan menganggap satu-satunya pemahaman mereka yang paling benar. Pemahaman demikian yang membuka pintu wacana terorisme dan pertarungan ideologoi keagamaan belahan dunia. Pasca tumbuhnya WTC di Amerika Serikat tahun 2001, terorisme yang 


\section{Hilmi Ridho}

mendapat dukungan dari gerakan radikalisme dan fundamentalisme kerap menjadi obyek dari tuduhan pelaku pengeboman. Tentu saja fenomena itu semakin memperkuat kecurigaan Barat terhadap dunia Islam. Namun menurut mayoritas kalangan internal Islam sendiri, mengatakan bahwa tidak semua aksi teroris itu mewakili umat muslim (Huntington, 2016).

Tahun 2018 menjadi sejarah dehumanisasi pemeluk agama Islam di Indonesia, pasalnya di tahun tersebut masyarakat Indonesia dikagetkan dengan aksi teror pengeboman di beberapa kota yang mengatasnamakan agama Islam. Aksi teror ini tidak ubahnya opera yang bertujuan menurunkan harga dan martabat umat Islam di hadapan agama lain. Tidak jarang para pelaku teror aksi pengeboman tersebut melakukan semua itu hanya semat-mata untuk memenuhi tuntutan teologi yang mereka pahami.

Islam seakan mengajarkan kepada para pengikutnya untuk menebarkan aksi terorisme sebagai wujud dari keimanan yang telah mereka pahami dari ajaran agama Islam. Doktrin teologi mereka mengeklaim kebenaran bahwa Tuhan telah menyuruhnya untuk melakukan apa saja yang mungkin demi membela agama-Nya. Padahal jika memhami Islam secara mendalam tidaklah demikian, justru Islam mengajarkan kepada umatnya agar bersikap toleransi, terbuka, dan saling mengasihi. Anasir demikian yang membawa kita harus terus belajar memahami arti dari pesan ajaran agama Islam yang moderat baik yang bersifat konseptual maupun praksis, tujuannya agar menepis anggapan tentang Islam yang keras dan ekstrem.

\section{Penutup}

Islam yang dibawa Nabi Muhammad Saw adalah agama Rahmatan Lil Alamiin, cenderung mengedepankan sikap moderasi, toleran dan damai. Tuduhan tidak mendasar bahwa agama Islam itu intoleransi dan tidak mengasihi terhadap agama lain, itu tidaklah benar. Mereka yang bersikap intoleransi mengatasnamakan Islam, hakikatnya tidak memahami arti dari Islam moderat yang damai dan santun baik yang terdapat dalam Alquran ataupun asas-asas Pancasila. Konsep moderasi dalam Alquran mengajarkan kita berhubungan baik dan adil kepada seluruh manusia, bahkan kepada saudara yang beda agama. Salah satu contohnya surah al-Baqarah :256 yang artinya "Tidak ada Paksaan dalam agama", hal ini merupakan wujud toleransi beragama sebagai konsep ajaran agama Islam. Lebih dari itu, sikap moderat apabila ditinjau dari asas-asas Pancasila; ketuhanan, persatuan dan kesatuan, kemanusisan, dan prinsip-prinsip berdialog, serta keadilan sangat selaras dengan konsep moderasi dalam Alquran. Ajaran moderasi baik dalam Alquran maupun Pancasila mengedepankan sikap damai, saling menghargai dan tidak 
mudah menyalahkan apalagi sampai pada mengkafirkan orang atau kelompok yang berbeda pandangan.

Sikap intoleransi yang dilakukan oleh beberapa oknum dengan mengatasnamakan agama Islam disebabkan oleh faktor internal individu yaitu kesalahpamahan umat muslim sendiri yang cenderung literalistik dalam memahami teks-teks keagamaan dengan menganggap pemahaman keislaman mereka yang paling benar. Sedangkan faktor eksternalnya dipengaruhi oleh masuknya ajaran Wahabisme yang memiliki kekuasaan politik untuk melakukan ekspansi wilayah dan penyebaran ajaran wahabi. Kekuasaan politik dijadikan media sebagai jalan untuk mnyebarkan ajaran Wahabi dengan menyerang, merusak dan memberantas tradisi masyarakat yang mereka pandang bid'ah dan bertentangan dengan tauhid.

Alquran dan asas Pancasila memberikan solusi untuk mengatasi problem intoleransi yang mengatasnamakan agama, diantaranya; pertama, menegakkan prinsip tawassuth (moderat), ta`adul (berkeadilan), dan tawazun (keseimbangan) kepada sesama manusia dalam beragama; baik umat muslim maupun non muslim. Keuda, menolak dengan keras masuknya ajaran-ajaran yang mengaku memiliki pemahaman Islam yang paling benar. Ketiga, menegakkan prinsip persatuan, kemanusiaan dan keadilan sebagaimana yang tertuang dalam asas-asas Pancasila sebagai ideologi negara. Keempat, kembali memahami ajaran Islam moderat yang benar sesuai ajaran agama Islam; baik secara konseptual maupun secara praksis.

\section{Daftar Rujukan}

'Âsyûr, Ibnu Muhammad at-Thahir. At-Tahrîr wa al-Tanwir, Juz II, Tunis: al-Dar Tunisiyyah, 1984.

'Âsyûr, Ibnu. Ushûl an-Nizhâm al-Ijtimâ'î fi al-Islâm, Tunis: As-Sharikah atTûnisiyyah li at-Tauzî',1979.

Al-Asfahaniy, al-Alamah al-Raghib, Mufradat al-Fadzul Qur'an, Dar al-Qalam: Baerut, 2009.

Al-Dimisyqiy, Ismail bin al-Katsir. Tafsir al-Qur'an al-`Azhim, (Kairo: Mu`assasah Qurtubah, 2000.

Ali, Dzul Faqqar. Mu'jam al-Wasith, Kairo: ZIB, 1973.

Arifinsyah. Dialog Qur'an dan Bibel; Menyikapi Pesan Suci Merajut Hubungan Antar Umat Beragam, Medan: CV. Manhaji Medan, 2016.

Azra, Azyumardi. "Fenomena Fundamentalisme dalam Islam: Survey Historis", Jurnal Ulumul Qur'an, Nomor 3, Vol. IV, (1993).

Bisri, A. Mustofa. "Islam Nusantara: Revolusi mental dan Amanat Hadratus Syaikh", Aula Majalah Nahdlatul Ulama No. 09 SNHXXXVII (September 2015).

Darlis. "Mengusung Moderasi Islam di Tengah Masyarakat Multikultural", dalam Jurnal Rausyan Fikr, Vol.13, No.2, (Desember 2017). 
Detik News, dalam https://news.detik.com/berita/4018835/bom-meledak-dirusunawa-sidoarjo-ada-5-orang-korban. Diakses pada tanggal 7 Nopember 2018, Jam 011:20.

Mun'im, Abdul. "Pergumulan Pesantren dengan Kebudayaan", dalam Badrus Sholeh (ed. ), Budaya Damai Komunitas Pesantren, Jakarta: LP3ES, 2007.

el-Fadl, Khaled M. Aboe. "Great Theft: Wrestling Islam for The Exremist", dalam Edy Susanto dan Karimullah, "Islam Nusantara: Islam Khas dan Akomodasi terhadap Budaya Lokal", dalam Jurnal al- Ulum, Vol.16, No.1, (Juni 2016).

Huntington, Samuel P."The Clash of Civilization and the Remaking of World Order", dalam Abdurrasyid, "Radikalisasi dan Moderasi: Studi Gerakan Islam Mainstrem Jama'ah Islamiyah dan Nahdatul Ulama di Indonesia", dalam Jurnal Penelitian Agama, Vol.7, No.3. (Desember 2016).

Mas'ud, Abdurrahman. Dari Haramain ke Nusantara: Jejak Intelektual Arsitek Pesantren, Jakarta: Kencana, , 2006.

Muhajir, Afifuddin. Membangun Nalar Islam Moderat Kajian Metodologis, Situbondo: Tanwirul Afkar, 2018.

Najib, Agus Moh. "Gerakan Wahabi: Ajaran dan Metode Penyebaran", dalam Yudian Wahyudi, ed. Gerakan Wahabi di Indonesia, Yogyakarta: Nawasea Press, 2009.

News Indonesia, dalam https://www.bbc.com/indonesia/indonesia44097913. Diakses pada tanggal 6 Nopember 2018, Jam 09:15.

Rahmat, M. Imdadun. "Islam Pribumi, Islam Indonesia", dalam M. Imdadun Rahmat (et al. ), Islam Pribumi: Mendialogkan Agama Membaca Realitas, Jakarta: Erlangga, 2003.

Zahrah, Muhammad Abu. Tarikh al-Mazahib al-Islamiyah Fi al-Siyasah wa alAqa'id. Beirut: Dar al-Fikr al-'Arabi, tt. 